\title{
The Evolution of Russian Emigration in the Post-Soviet Period
}

\author{
Ivan Aleshkovski
}

Lomonosov Moscow State University

\author{
Alexander Grebenyuk \\ Lomonosov Moscow State University
}

\section{Olga Vorobyeva \\ MGIMO University}

\begin{abstract}
The article deals with emigration from Russia in the period between the late twentieth and early twenty-first centuries. The emigration from Russia has changed significantly since the early 1990s. On the basis of quantitative and qualitative analyses, the authors identify five major waves of emigration characterized by specific major categories of emigrants and motives for emigration. They examine the scales and structural characteristics of various flows of emigration, especially with regard to their age aspect. The analyses reveals that different waves of migration predominantly involve people of certain age groups, and the impact of these waves on the general population age structure will be markedly different, so that the results of this research can further be applied to modeling Russian age structure at various retrospective scenarios. The authors' comparative studies of statistics published by the Russian Federal State Statistical Agency and the statistical agencies of foreign countries show major discrepancies, suggesting that Russian data underplay the scale of emigration of Russian citizens.
\end{abstract}

\section{INTRODUCTION}

The term emigration (derived from Latin 'emigro', which means 'to depart from a place') means moving from one's country of origin to another country to live there permanently or for a certain period of time for various reasons. As any other form of migration, emigration may be voluntary or forced. Voluntary emigration implies that one's country of origin offers lower living standards or worse prospects than the host country. Since voluntary emigration does not imply changing from better to worse, any

Social Evolution \& History, Vol. 17 No. 2, September 2018 140-155

(C) 2018 'Uchitel' Publishing House

DOI:10.30884/seh/2018.02.09 
country facing emigration should admit that its living standards or prospects for it population are worse than those in the countries that the emigrants leave for. Therefore, the analysis of Russian emigration can help identify social, economic, political, ecological and other circumstances that do not satisfy some Russians and make them emigrate.

In the second half of the 1980s and in the early 1990s social, economic and political transformations led to highly intensive cross-border migrations among former citizens of the Soviet Union. Over a few years' time, Russia, previously a closed country, became actively involved in international migration processes, acting simultaneously as a country of origin, a host country, and a transit country (Iontsev 1999; Iontsev and Aleshkovski 2008).

The voluntary emigration from Russia began to gain momentum in the late 1980s after the country had loosened its emigration regime and departure registration procedures. Until 1989, virtually no free emigration from the USSR was possible. After the year 1989 exceptions were made for emigration of ethnic Germans, Jews, and Greeks.

There was a considerable increase of emigration starting from January 1, 1993, when entry and exit rules were liberalized (i.e., the date the Law on Entry and Exit, adopted earlier by the USSR People's Deputies, came into force). The Russian Constitution of 1993 also stipulated the right of citizens to freely leave the Russian Federation and the right to return to the country ('Everyone may freely leave the Russian Federation. The Russian citizens shall have the right to freely return to the Russian Federation').

The studies conducted by the Russian scholars (Aleshkovski 2011; Aleshkovski and Bocharova 2014; Akhiezer 1999; Denissenko 2003; Iontsev 1999, 2001; Zaionchkovskaya 2001; Polyan 2005; Ushkalov, Malakha 1999; Rybakovsky, Lokossov 2014; Ryazantsev and Grebenyuk 2014) shows that between 1990 and 2000 the emigration from Russia was not static but changed in structure and scale. While some of the emigration stimuli were fading, others were coming into existence. This situation discouraged some social groups from emigrating but led to a stronger desire to emigrate among others.

The changes in migration sentiments and channels resulted in several waves of emigration from Russia between 1990 and 2000. The initial emigration from the Soviet Union was triggered by a severe economic and political crisis in the country caused by transformation processes and reforms of social and economic relations. Since the early emigration opportunities largely depended on the host countries' immigration policies which primarily encouraged ethnicity as the reason for immigration, the initial waves of emigration from Russia were mostly ethnic (ethnic German, Jewish and mixed families were the most frequent emigrants). As a result, the main immigration countries for the Russians were Israel, Germany and the United States. 
Of course, this does not mean that those countries were the only destinations for Soviet and Russian emigrants, but in the first half of the 1990s those countries were predominant destinations.

In subsequent years the emigration sentiments in Russia prevailed mostly among social groups that used opportunities to freely leave the country to find qualified and well-paid jobs, to pursue business in a more favourable market environment, and to live permanently in a more comfortable and secure place. There were also broader opportunities to study abroad. Host countries had the following channels of legalization of immigrants: refugees, ethnic migrants, scientists, employment, entrepreneurship, middle-class emigration, students, and reunification of families.

\section{THE SCALE OF EMIGRATION FROM RUSSIA BETWEEN THE 1990s AND 2000s}

According to Rosstat, approximately $4.2 \mathrm{mln}$ citizens left the Russian Federation between 1990 and 2017 (see Table 1). Most of them left Russia in the early 1990s (e.g., there were about 700,000 registered emigrants in 1992 and 500,000 in 1993). In subsequent years, the number of emigrants gradually decreased and reached its minimum of 29,467 in 2011, according to Rosstat. After 2011, the number of emigrants has been increasing steadily again.

The Number of Emigrants from the Russian Federation, 1990-2017

\begin{tabular}{|c|c|c|c|}
\hline Year & $\begin{array}{c}\text { Number of emigrants, } \\
\text { persons }\end{array}$ & Year & $\begin{array}{c}\text { Number of emigrants, } \\
\text { persons }\end{array}$ \\
\hline 1990 & 103,694 & 2004 & 76,570 \\
\hline 1991 & 88,347 & 2005 & 66,820 \\
\hline 1992 & 704,136 & 2006 & 51,791 \\
\hline 1993 & 493,119 & 2007 & 45,071 \\
\hline 1994 & 345,623 & 2008 & 37,982 \\
\hline 1995 & 347,338 & 2009 & 30,869 \\
\hline 1996 & 291,642 & 2010 & 31,734 \\
\hline 1997 & 232,987 & 2011 & 29,467 \\
\hline 1998 & 213,377 & 2012 & 46,687 \\
\hline 1999 & 214,963 & 2013 & 47,439 \\
\hline 2000 & 145,720 & 2014 & 52,235 \\
\hline 2001 & 121,166 & 2015 & 51,846 \\
\hline 2002 & 100,732 & 2016 & 58,739 \\
\hline 2003 & 89,971 & 2017 & 66,735 \\
\hline
\end{tabular}

* 1990-1991: the number of persons admitted for resident permits and departing to settle abroad; 2002-2017: number of Russian citizens, emigrated from Russia.

Source: data from the Federal State Statistics Service of the Russian Federation (URL: http://www.gks.ru). 
Noteworthy, the comparison of a benchmark analysis of data from foreign national and international statistics organizations with data from Rosstat shows significant discrepancies in relevant quantitative indicators of the Russian emigration flows with Russian statistics tending to underestimate the intensity of emigration (Table 2).

Comparative Analysis of Russian and Foreign Statistics on Emigration from Russia

\begin{tabular}{|c|c|c|c|c|c|c|}
\hline & \multicolumn{2}{|c|}{2012} & \multicolumn{2}{|c|}{2013} & \multicolumn{2}{|c|}{2014} \\
\hline & 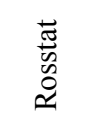 & 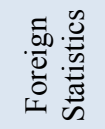 & $\begin{array}{l}\frac{\pi}{\pi} \\
\text { D } \\
0 \\
0 \\
\simeq\end{array}$ &  & $\begin{array}{l}\underset{\pi}{\pi} \\
\dot{\mathscr{N}} \\
0 \\
0\end{array}$ & 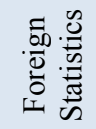 \\
\hline Australia & 220 & 1,177 & 255 & 1,399 & 308 & 1,220 \\
\hline Austria & 122 & 3,438 & 141 & 3,471 & 157 & 3,139 \\
\hline Austria & 122 & 3,438 & 141 & 3,471 & 157 & 3,139 \\
\hline Canada & 494 & 1,960 & 536 & 2,350 & 691 & 1,780 \\
\hline Czech Republic & 292 & 3,201 & 281 & 3,050 & 303 & 5,862 \\
\hline Finland & 572 & 3,050 & 715 & 2,875 & 1,016 & 3,179 \\
\hline Germany & 3,781 & 20,714 & 3,979 & 33,233 & 4,780 & 23,352 \\
\hline Israel & 1,104 & 3,566 & 1,090 & 4,094 & 1,139 & 4,647 \\
\hline Japan & 86 & 3,829 & 134 & 2,540 & 146 & 3,047 \\
\hline Poland & 114 & 1,871 & 133 & 1,894 & 192 & 1,113 \\
\hline South Korea & 136 & 2,723 & 474 & 2,846 & 417 & 3,207 \\
\hline Spain & 405 & 7,820 & 403 & 8,617 & 437 & 8,286 \\
\hline Switzerland & 125 & 2,057 & 96 & 2,145 & 166 & 1,914 \\
\hline UK & 242 & 4,300 & 255 & 1,300 & 399 & 3,200 \\
\hline USA & 1,561 & 9,969 & 1,485 & 9,753 & 1,937 & 9,079 \\
\hline
\end{tabular}

Source: data from the Federal State Statistics Service of the Russian Federation (URL: http://www.gks.ru), the Organization for Economic Co-operation and Development (OECD, URL: http://www.oecd.org/els/mig/keystat.htm), and foreign statistical services.

With respect to some countries, there are significant (tenfold-plus) discrepancies in statistics. It must be admitted, therefore, that, due to the gaps in the migration registration system, a large proportions of people leaving Russia are not documented by Rosstat. For example, the number of emigrants from Russia to Israel in 2014 as reported by Rosstat was one 
quarter of that reported by the Israeli Ministry of Aliyah and Integration; similarly, according to Rosstat, the number of Russian immigrants into the United States as registered by the US Census Bureau was 4.7 times as large as that reported by Rosstat; and finally, the number of emigrants to Germany as announced by Rosstat was one-fifth of that reported by the German Federal Statistical Office.

Thus, we believe that, on average, the data provided by the Russian Federal State Statistics Service should be multiplied by a factor of three or four to accurately describe the emigration scales from Russia. However, such corrections should not be mechanical - they should reflect changes in emigration registration principles in Russia and host countries. For instance, in 2011, Russia overhauled the procedures for statistical registration of incomers (to include all those who had lived in Russia for nine months vs. 12 months as had been the case until 2012). As a result, in 2012, as compared to 2011, the number of people registered as having entered Russia as well as the number of persons registered as having left it significantly increased. However, this migration inflow, which has been increasing since 2012, actually reflects data on the majority of labour migrants (the CIS countries account for three quarters of labour migrants' exit countries and their destinations after leaving Russia, but there are no active migrations with regard to permanent residence change to or from those countries). Until now, this information has not accurately reflected the situation with emigration.

Our analysis of Rosstat data on the geography and structure of emigration flows has enabled us to identify the following aspects of emigration from Russia:

- the emigration from Russia to developed countries is characterized by high-quality human capital (high educational and professional levels and a relatively young age), i.e. the most economically active individuals;

- the geography of emigration from Russia is expanding, and emigration from border regions and regions with a high economic growth rate is increasing in scale. The Russian regions that are socially and economically depressed have minimum emigration levels;

- personal and family motives are the main reasons for emigration; surveys suggest that reasons for emigration also include poor prospects for the improvement of one's material status, social status, personal stability and economic security.

\section{RUSSIAN EMIGRATION WAVES BETWEEN 1990 AND 2017}

The quantitative and qualitative analyses of national and foreign statistics on emigration from Russia suggest some generalizations and periodizations.

Instead of the scale and volume of emigration (which naturally evolved during the years under consideration) we propose the segmenta- 
tion criterion using qualitative changes in the structure and geography of emigration flows and channels through which migrants from Russia are legalized in their host countries. On the basis of our analysis, we have identified five waves or stages of modern Russian emigration. The shift from one stage to another was caused by social, political and economic changes in Russia and by legislation changes in host countries.

Wave I (1990-1994). The first half of the 1990s witnessed an intensive acceleration of emigration provoked by the political and economic reforms in Russia causing mass unemployment (Fig. 1). The ethnic migrants and members of intellectual elites (scientists and high-skilled professionals) had the best chances to receive support in the host countries under hosting or refugee programmes. However, the first-wave emigrants faced unfamiliar and sometimes frightening conditions.

The first wave was the largest in Russia's post-Soviet history. There are no accurate Russian statistics for 1990 or 1991. It is only known how many permits were issued for leaving Russia for permanent residence abroad. The statistics for the period from 1992 to 1994 show that approximately $1.5 \mathrm{mln}$ people emigrated; meanwhile, we estimate that approximately $2.1 \mathrm{mln}$ people left Russia during that wave. The Western experts made apocalyptic forecasts that tens of millions of people could leave the country in case the negative social and economic trends in the former Soviet Union continued further. Nevertheless, the crisis soon bottomed out, the situation stabilized, the most mobile part of population had left Russia, and after 1993 emigration decreased in quantitative terms (Fig. 1).

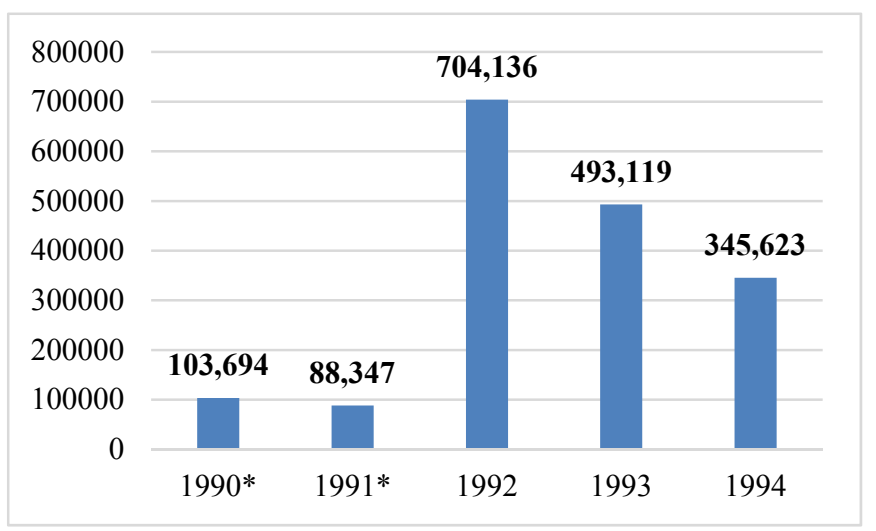

Fig. 1. Emigration from Russia in 1990-1994, persons

* Data for 1990 and 1991 show numbers of exit permits for permanent residence abroad issued.

Source: Rosstat. 
Here we should return to the discrepancies between the Russian and foreign statistics on emigration from Russia. For example, while, according to the German Federal Statistics Office, the number of Russians who arrived in Germany in 1992 was by 25 per cent larger than reported by Rosstat, in 2016 Rosstat failed to record more than 81 per cent of this emigration flow (Table 3).

Table 3

Comparative Analysis of Russian and German statistics on Russian emigration to Germany in 1992-2016

\begin{tabular}{|l|c|c|c|c|c|c|c|c|c|}
\hline & $\mathbf{1 9 9 2}$ & $\mathbf{1 9 9 7}$ & $\mathbf{2 0 0 2}$ & $\mathbf{2 0 0 7}$ & $\mathbf{2 0 1 0}$ & $\mathbf{2 0 1 1}$ & $\mathbf{2 0 1 2}$ & $\mathbf{2 0 1 4}$ & $\mathbf{2 0 1 6}$ \\
\hline $\begin{array}{l}\text { Data accor- } \\
\text { ding to Ger- } \\
\text { man Federal } \\
\begin{array}{l}\text { Statistical Of- } \\
\text { fice, persons }\end{array}\end{array}$ & 84,509 & 67,178 & 77,403 & 20,487 & 18,671 & 19,696 & 20,714 & 23,352 & 24,983 \\
\hline $\begin{array}{l}\text { Data accor- } \\
\text { ding to Ros- } \\
\text { stat, persons }\end{array}$ & 62,700 & 48,363 & 42,231 & 6,486 & 3,725 & 3,815 & 3,781 & 4,780 & 4,694 \\
\hline $\begin{array}{l}\text { Difference } \\
\text { between Rus- } \\
\text { sian and } \\
\text { German data }\end{array}$ & 21,809 & 18,815 & 35,172 & 14,001 & 14,946 & 15,881 & 16,933 & 18,572 & 20,289 \\
\hline $\begin{array}{l}\text { Share of emi- } \\
\text { gration flow } \\
\text { not recorded } \\
\text { by Rosstat, \% }\end{array}$ & 25.8 & 28.0 & 45.4 & 68.3 & 80.0 & 80.6 & 81.7 & 79.5 & 81.2 \\
\hline
\end{tabular}

Source: Data from the Federal State Statistics Service of the Russian Federation (URL: http://www.gks.ru) and the German Federal Statistical Office (https://www.destatis.de/EN/Homepage.html).

The emigrants were mostly middle-class people who highly appreciated migration support programmes. Most of the emigrants were people of middle working age or beyond with high professional standards or scientists and experts with unique knowledge in their fields. The shares of men and women in this emigration wave were approximately equal.

The main host countries for Russian emigrants were Germany, Israel and the United States. In 1993, those three countries received 94.2 per cent of Russian emigrants leaving for countries outside the territory of the former Soviet Union, and in 1994 the proportion was 94.4 per cent. 


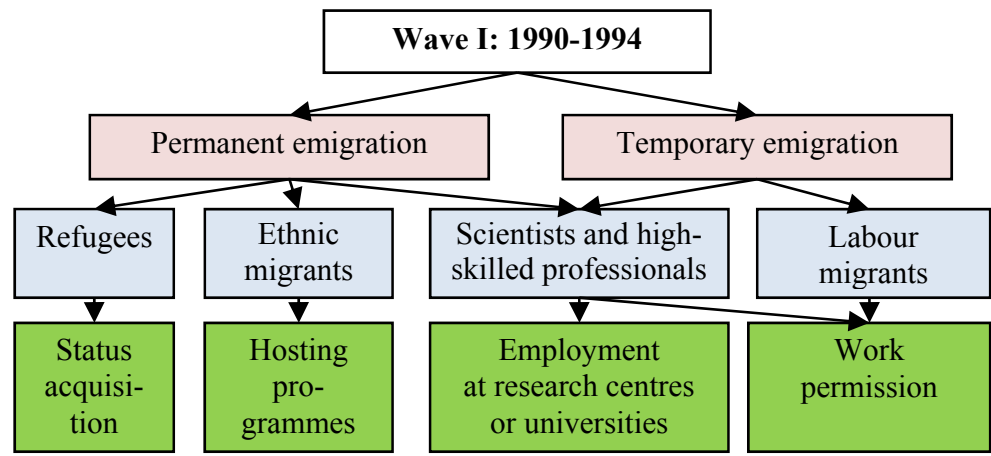

Qualitative structure of migrants: high education and professional standards, men and women of working-age and beyond, family members

\1

USA, Israel, Germany

Fig. 2. The first wave of emigration from contemporary Russia

Wave II (1995-2000). In the second half of the 1990s, Russians looking for employment joined the increasing number of temporary labour migrants filling various niches in developed labour markets (from lowskilled jobs to positions requiring better education and high qualifications) (Fig. 4). Initial capital accumulation was still in progress in Russia, and therefore there was no large-scale business emigration with the export of large amounts of capital for independent living abroad. Russians started to rapidly explore commercial and entrepreneurial activities. However, they were not immediately followed by their children or other family members.

According to Rosstat, $1.47 \mathrm{mln}$ people left Russia in this period (1995-2000). The emigration decreased in volume due to two factors: the relatively weakened social crisis and the fact that a large share of the most mobile part of population had already left the country (Fig. 3). At the same time, according to our estimations, the total number of second-wave migrants was approximately $2 \mathrm{mln}$. 


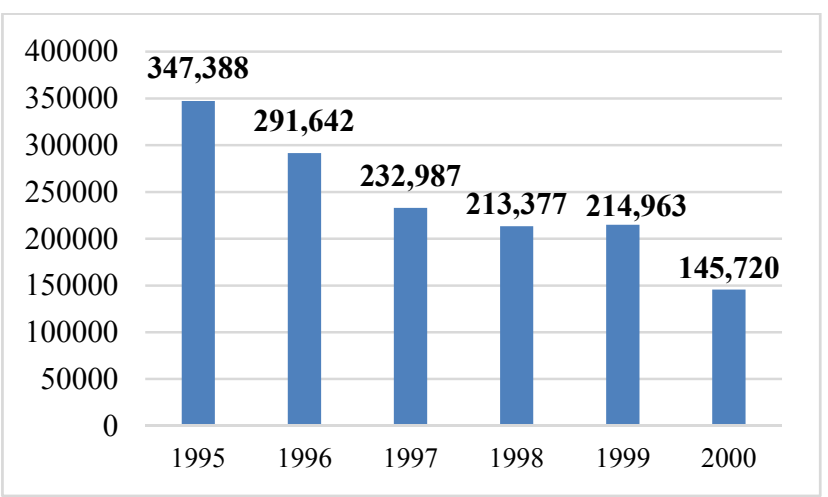

Fig. 3. Emigration from Russia in 1995-2000, persons

Source: Rosstat.

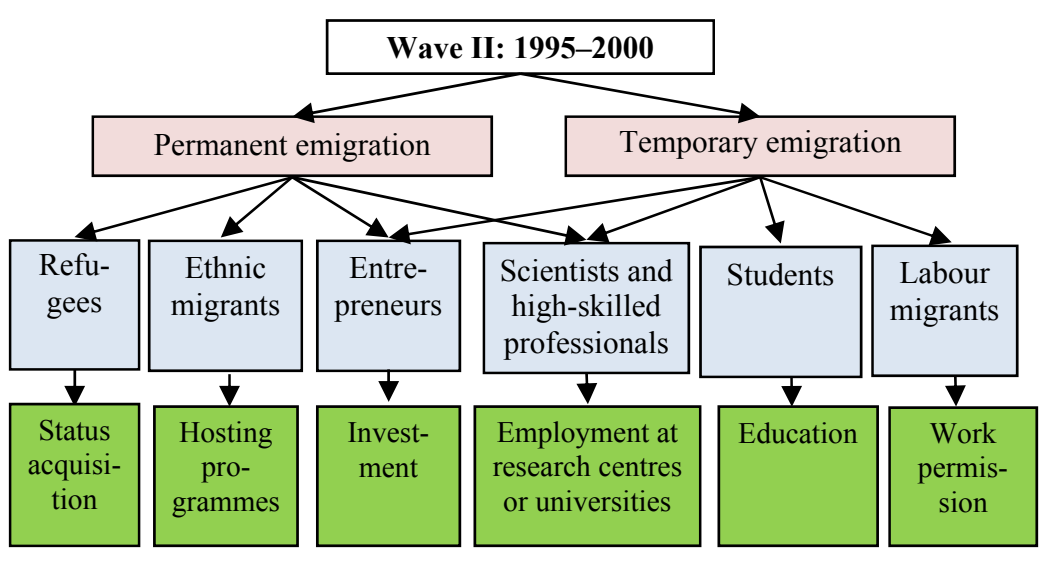

Qualitative structure of migrants:

high education standards, 'new' businesspeople, financiers, qualified professionals, mostly working-age individuals

US, Germany, Israel, Canada, Finland, Greece, Bulgaria

Fig. 4. The second wave of emigration from contemporary Russia

The educational migration increased in that period, but just as a step towards further emigration and integration into host societies. Marital migration, mostly female, became more organized and grew rapidly. Refugee status was still sought but not so frequently. 
Wave III (2001-2005). In the early 2000s, interest in economic partnership with other countries became one of the significant drivers of emigration. According to Rosstat, 455.26 thousand citizens left Russia in this period (Fig. 5).

At this stage, business emigration from Russia was growing steadily, with Russian business people focusing on more quiet and secure Western markets. The affluent social groups had the opportunity to buy real estate for permanent or temporary residence. Sending children to study abroad became the most popular way of finding a more prosperous and democratic place for them to live. Those children hardly ever returned to Russia after finishing their studies. This period was characterized by an increasing outflow of young people who had received a good technological education in Russia but could not find a well-paid job in a public or private corporation. Marital migration was on the increase as well. The internal geography of Russian emigration expanded, and now emigrants represented all Russian regions. The proportion of Muscovites and St Petersburg residents emigrating to the United States shrank from 30 to 9 per cent.

As said above, the Rosstat statistics on the third-wave emigration significantly differ from foreign data. While the Russian statistics show that a little less than half a million people left Russia in that period, our own estimates based on foreign statistics enlarge the number of Russians who left the country in those years to about one million.

Wave IV (2006-2011). The second half of the 2000s was characterized by another economic crisis (2008-2009). Rising unemployment and a shrinking domestic market made the Russian business people look for business opportunities abroad. According to experts, they made up the largest proportion of emigrants at that time. Other forms of emigration such as migration for study or migration of graduates in search of jobs were still widely spread (Fig. 6).

It is even more difficult to estimate the quantitative scale of emigration during the period than in previous periods. The official statistics record only approximately 30 per cent of total emigration. According to Rosstat, about 227 thousand citizens left the country during the fourth wave (2006-2011). However, the USA, German, Spanish and Israeli official statistics show that about 237,000 immigrants from Russia entered those countries (Table 4). Therefore, taking into account all countries that attracted Russian emigrants, whose numbers had increased significantly by that time, the total number of those who left the country may be as large as 400 thousand. 
150 Social Evolution \& History / September 2018

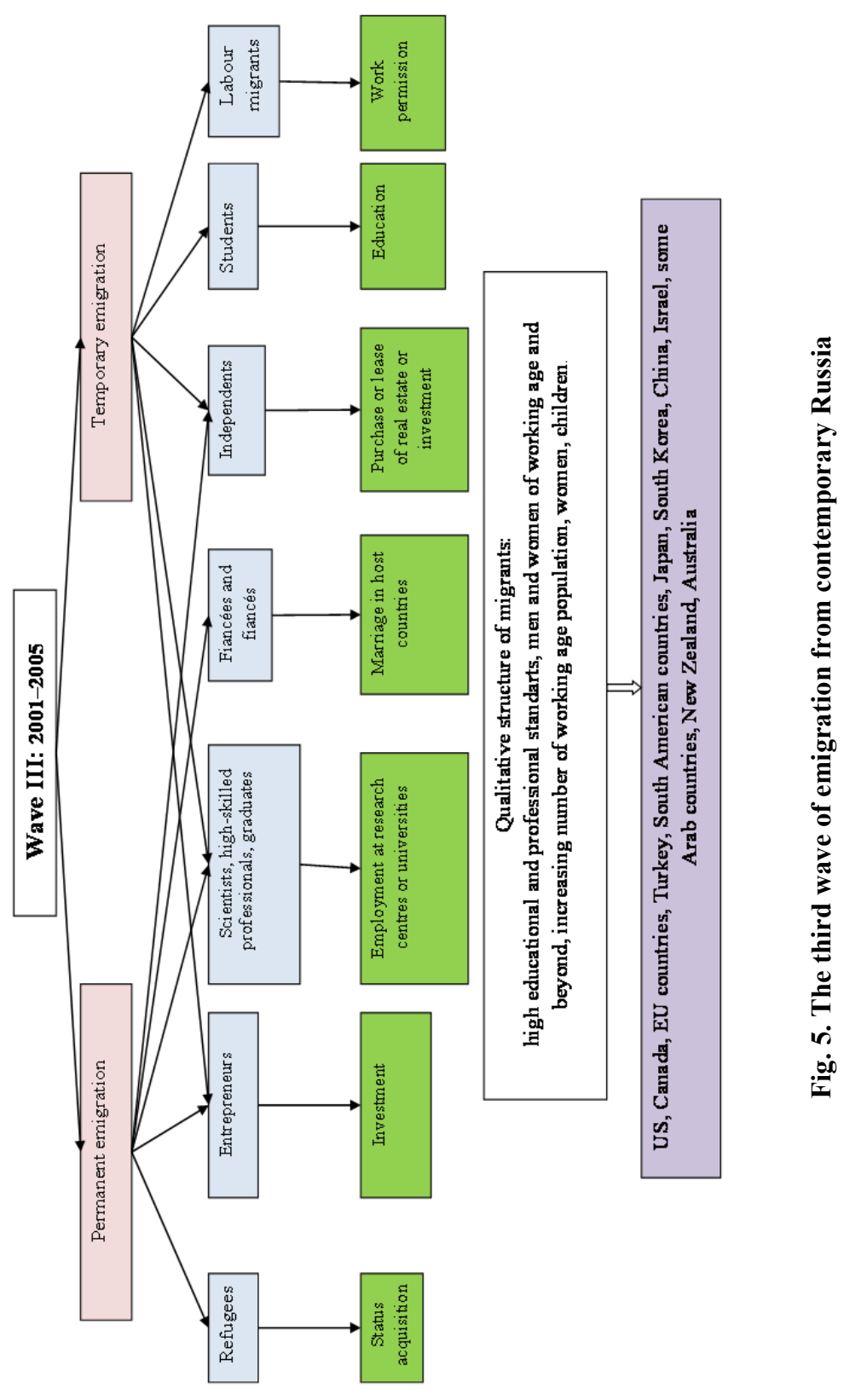




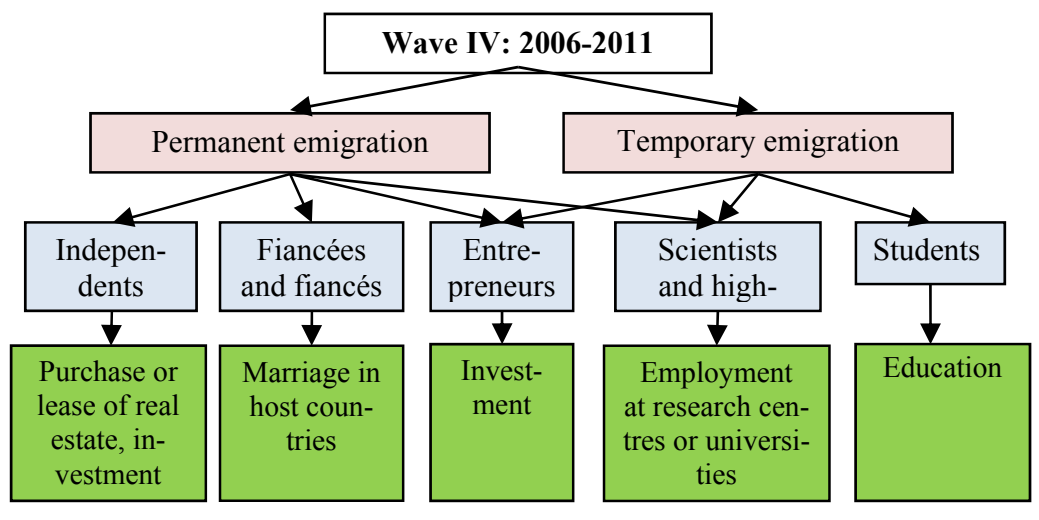

Qualitative structure of migrants:

continuing growth of the proportion of young members of the economically active population and children

US, Canada, EU countries, Turkey, China, Israel, Australia, South Korea, Japan, South American countries and Middle Eastern coun-

Fig. 6. The fourth wave of emigration from contemporary Russia

Immigration from Russia

Table 4

\begin{tabular}{|l|c|c|c|c|c|c|c|}
\hline Country & 2006 & 2007 & 2008 & 2009 & 2010 & 2011 & Total \\
\hline US & 13,159 & 9,426 & 11,695 & 8,238 & 6,718 & 7,944 & $\mathbf{5 7 , 1 8 0}$ \\
\hline Germany & 23,241 & 20,487 & 18,611 & 18,615 & 18,671 & 19,696 & $\mathbf{1 1 9 , 3 2 1}$ \\
\hline Israel & 3,602 & 3,370 & 2,693 & 3,314 & 3,515 & 3,762 & $\mathbf{2 0 , 2 5 6}$ \\
\hline Spain & 8,041 & 7,276 & 5,750 & 5,290 & 6,174 & 7,640 & $\mathbf{4 0 , 1 7 1}$ \\
\hline Total & $\mathbf{4 8 , 0 4 3}$ & $\mathbf{4 0 , 5 5 9}$ & $\mathbf{3 8 , 7 4 9}$ & $\mathbf{3 5 , 4 5 7}$ & $\mathbf{3 5 , 0 7 8}$ & $\mathbf{3 9 , 0 4 2}$ & $\mathbf{2 3 6 , 9 2 8}$ \\
\hline
\end{tabular}

Source: $\mathrm{UN}$ and foreign statistical services.

By the time, the Russian immigrants had comfortably established communities in the main host countries of Russian emigration. Those communities became a kind of magnets for close and distant relatives and acquaintances whom many of the immigrants had left in Russia and who began to think about emigrating.

The potential emigrants from Russia were attracted by immigrants' successful experience of employment, by chances of solution of housing and other social problems, and by the opportunities to get access to social services enjoyed by the native population of the potential host countries. 
The living standards of those leaving Russia were going up. It is no surprise that Russian regions with relatively high social and economic indicators were among those with higher emigration rates. Emigrants included more and more former civil servants and their families and families of members of political, bureaucratic and financial elites who preferred peaceful, stable and secure life in the Western countries to Russian reality.

In the meantime, Russian emigrants started to settle in more distant countries and continents. At that stage, the average Russian emigrant was younger, adapted more easily to the environment and rules of the host country, and could easier dismantle the language barrier. But at the same time, emigration became a threat to the demographic, social and economic development of Russia.

Wave V. The latest emigration wave started in 2012 and is still in progress. The emigration at this stage does not essentially differ from the fourth wave (Fig. 7). The Russian immigration to various countries reached the point when family reunification is the most common channel for entry and naturalization. New emigrants are members of the families of yesterday's emigrants and represent all major layers of the Russian society: business people, students, independents, scientists and professionals. The emigration from border regions has grown during this wave.

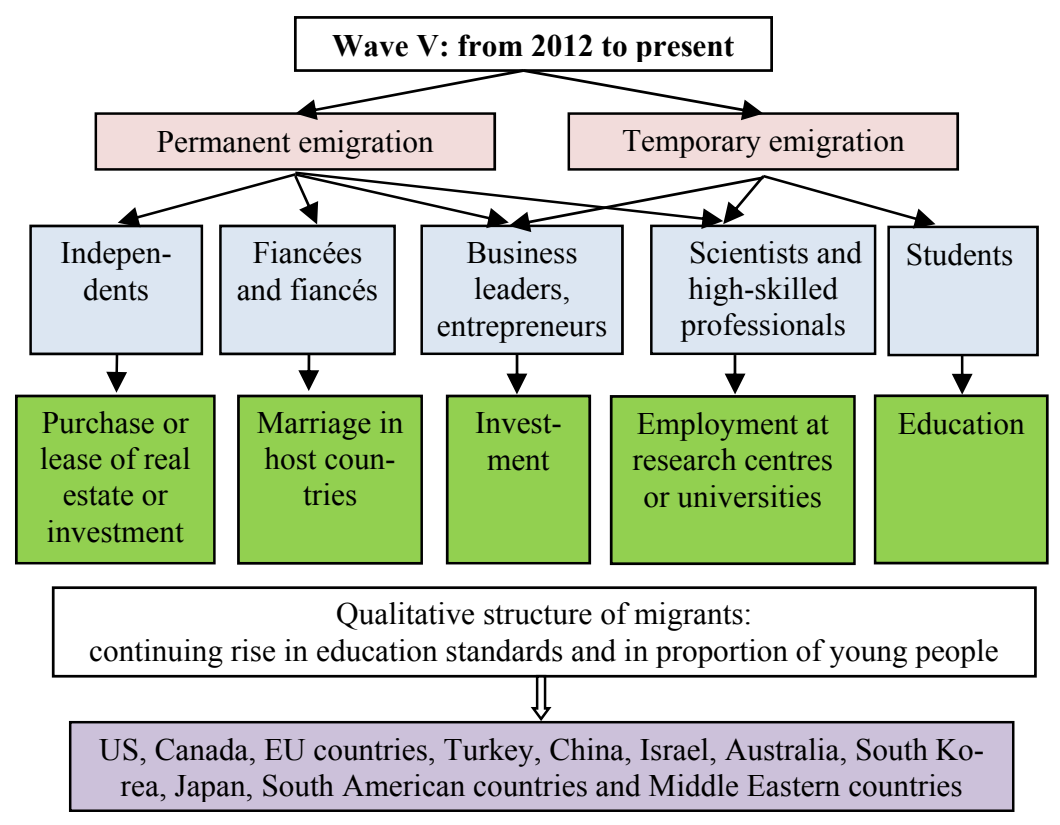

Fig. 7. The fifth wave of emigration from contemporary Russia 
At this stage, the emigration sentiments in Russia have gathered momentum, and the current emigration wave promises to be significantly larger than the previous one. According to Rosstat, 323.68 thousand citizens left Russia between 2012 and 2017 while the foreign statistics suggests that number to be approximately 500 thousand.

A selective approach used by economically developed countries continues to pull valuable human capital out of Russia - educated and energetic people who are under 35 years old and seek better jobs and higher living standards. According to surveys, many of them are dissatisfied with the current economic and social situation in the country and see no prospects for themselves in today's Russia. Russia's regions with the highest social and economic development levels are among those with the highest emigration rates, and this makes it obvious that Russia has exhausted its opportunities to raise living standards.

\section{CONCLUSIONS}

The quantitative and qualitative analyses of emigration from Russia over the past 25 years has brought us to the following conclusions.

First, the actual numbers of emigrants are much larger than those recorded in official statistics. We estimate that approximately $6.0 \mathrm{mln}$ citizens left Russia between 1990 and 2017 (Table 5).

Table 5

Emigration from Russia in 1990-2017, mln people

\begin{tabular}{|l|c|c|}
\hline \multicolumn{1}{|c|}{ Emigration waves } & Rosstat & Authors' estimate \\
\hline Wave I (1990-1994) & 1.5 & 2.1 \\
\hline Wave II (1995-2000) & 1.47 & 2.0 \\
\hline Wave III (2001-2005) & 0.47 & 1.0 \\
\hline Wave IV (2006-2011) & 0.23 & 0.4 \\
\hline Wave V (2012-2017) & 0.32 & 0.5 \\
\hline Total & 3.99 & 6.0 \\
\hline
\end{tabular}

Second, the emigration is an increasing threat to Russia as it erodes the country's demographic, socioeconomic and intellectual potential.

Third, the emigrants who left in the 1990s and 2000s fell into the following categories: refugees, ethnic migrants, scientists, employment seekers, entrepreneurs, members of the middle class, students, and people seeking unification family members.

Fourth, high education standards, high professional skills, a high material status and a relatively young age are characteristics common for all emigration waves.

Fifth, the emigration from Russia has changed in character over the last decade. The current emigration is largely economically motivated and 
caused by differences in living standards and the quality of life between Russia and many host countries.

\section{ACKNOWLEDGEMENTS}

This research has been supported by Russian Science Foundation Project No. 17-78-20096.

\section{REFERENCES}

Akhiezer, A. S. 1999. Emigration as a Status Indicator of the Modern Russian Society. Mir Rosii 4: 163-175. In Russian (Ахиезер А. С. Эмиграция как индикатор состояния Российского общества. Мир России 4: 163-175).

Aleshkovski, I. A, and Bocharova, Z. S. 2014. Russia in the Global Migration Flows: History and Modern Times. Moscow University Bulletin. Series 27. Global Studies and Geopolitics 3-4: 3-24. In Russian (Алешковский И. А., Бочарова 3. С. Россия в глобальных миграционных миграционных потоках: история и современность. Вестник Московского университета. Серия 27 «Глобалистика и геополитика» 3-4: 3-24).

Aleshkovski, I. A. 2011. International Migration Trends in Contemporary Russia in the Context of Globalization. Vek globalizatsii 1: 159-181. In Russian (Алешковский И. А. Тенденции международной миграции населения в современной России в условиях глобализации. Век глобализачии 1: 159-181).

Denissenko, M. B. 2003. Emigration from Russia Based on the Foreign Statistics. Mir Rosii 3: 157-169. In Russian (Денисенко М. Б. Эмиграция из России по данным зарубежной статистики. Мир России 3: 157-169.)

Iontsev, V. A. 1999. International Migration: the Theory and the History of Research. In International Migration of Population: Russia and the Contemporary World. Moscow: Dialog-MGU. Issue 3. In Russian (Ионцев В. А. Международная миграция: теория и история изучения // Международная миграция населения: Россия и современный мир. М.: Диалог-МГУ, 1999. Вып. 3).

Iontsev, V. A., and Aleshkovski, I. A. 2008. International Migration Trends in the Globalizing World. Vek globalizatsii 2: 77-87. In Russian (Ионцев В. А., Алешковский И. А. Тенденции международной миграции в глобализирующемся мире. Век глобализаиии 2: 77-87).

Iontsev, V. A., Lebedeva, N. M., Nazarov, M. V., and Okorokov, A. V. 2001. Emigration and Repatriation in Russia. Moscow: Caring About the Needs of the Russian Repatriates. In Russian (Ионцев В. А., Лебедева Н. М., Назаров М. В., Окороков А. В. Эмиграция и репатриация в России (в соавторстве). М.: Попечительство о нуждах российских репатриантов).

Lokossov, V. V., and Rybakovsky, L. L. (eds.) 2014. Migration Processes in Russia. Moscow: Econ-Inform. In Russian (Миграционные процессы в 
России / Под ред. В. В. Локосова и Л. Л. Рыбаковского. М.: Эконинформ).

Polyan, P. 2005. Emigration: Who and When Left Russia in 20th Century. In Glezer, O., and Polyan, P. (eds.), Russia and Its Regions in $20^{\text {th }}$ Century: the Territory - Displacements - Migrations (pp. 493-519). Moscow: OGI. In Russian (Полян П. Эмиграция: кто и когда в XX в. покидал Россию // Россия и ее регионы в XX веке: территория - расселение миграции / под ред. О. Глезер, П. Поляна. М.: ОГИ. С. 493-519).

Ryazantsev, S. V., and Grebenyuk, A. A. 2014. 'Our people' Abroad. The Ethnic Russians, the Russians, the Russian Speaking, Compatriots: Settlement, Integration, and Return Migration to Russia. Moscow: ISPI RAN. In Russian (Рязанцев С. В., Гребенюк А. А. «Наши» за гранищей. Русские, россияне, русскоговорящие, соотечественники: расселение, интеграџия и возвратная миграџия в Россию. М.: ИСПИ РАН).

Ushkalov, I. G., and Malakha, I. A. 1999. Brain Drain: Scale, Reasons, and Consequences. Moscow: Editorial URSS. In Russian (Ушкалов И. Г., Малаха И. А. «Утечка умов»-масштабы, причины,, последствия». М.: Эдиториал УРСС).

Vorobyeva, O. D., Alechkovski, I. A., and Grebenyuk, A. A. 2017. Transformation of Emigration from Russia at the End of the $20^{\text {th }}$ and Beginning of the $21^{\text {st }}$ Centuries. Vek globalizatsii 4: 100-111. In Russian (Воробьева О. Д., Алешковский И. А., Гребенюк А. А. Трансформация российской эмиграции на рубеже XX-XXI веков. Век глобализации 4: 100-111).

Zaionchkovskaya, Zh. A. 2001. Emigration to Far-Abroad Countries. Demoscope Weekly 27-28, July 30 - August 12. In Russian (Зайончковская Ж. А. Эмиграция в дальнее зарубежье. Демоскоn Weekly 27-28, 30 июля - 12 августа). 